\title{
Cryptic alternative male mating strategies in invasive alien round goby (Neogobius melanostomus) of the upper Danube River
}

\author{
Alexander F. Cerwenka $(\mathbb{D} \cdot$ Joerg Brandner · Juergen Geist • Ulrich K. Schliewen
}

Received: 29 May 2020/ Accepted: 8 October 2020/Published online: 23 October 2020

(C) The Author(s) 2020

\begin{abstract}
Male alternative mating strategies are a widespread life history choice, yet they have hardly been assessed in the context of fish invasions. As established proxies for alternative life-history strategies, body length and sexual maturity of PontoCaspian round goby (Neogobius melanostomus) from the recently invaded upper Danube River were contrasted and differential trophic niche occupation was assessed. Only about $4 \%$ of analyzed gobies qualified as potential sneakers which may be explained by the recent and ongoing invasion process. This study provides evidence for the occurrence of sneaking behavior of invasive round goby in the upper Danube River.
\end{abstract}

Keywords Neogobius melanostomus - Alternative male mating tactic $\cdot$ Reproductive tactics $\cdot$ Sneaking . Gonado-somatic index $\cdot$ Lipid content

A. F. Cerwenka · U. K. Schliewen $(\bowtie)$

SNSB-ZSM Bavarian State Collection of Zoology,

Münchhausenstraße 21, 81247 Munich, Germany

e-mail: schliewen@snsb.de

J. Brandner

Wasserwirtschaftsamt Regensburg, Landshuter Str. 59, 93053 Regensburg, Germany

J. Geist

Aquatic Systems Biology Unit, School of Life Sciences Weihenstephan, Technical University of Munich,

Mühlenweg 22, 85350 Freising, Germany

\section{Introduction}

Numerous and taxonomically widespread alternative reproductive strategies evolved within males, especially in species with (1) external fertilization, (2) egg guarding, or (3) high competition for a mating occasion (Taborsky et al. 2008). Their occurrence appears to be correlated with keen competition for mating opportunities, e.g. spawning localities or partners, and with alternative strategies paying off equally or higher concerning fitness. Sneaking, i.e. a parasitic alternative reproductive behavior used to exploit the reproductive investment of conspecific rival males, is a well-known alternative reproductive strategy (Taborsky et al. 2008). Sneakers have to invest in sperm quality and quantity, as they are confronted with high sperm competition during every mating (Taborsky et al. 2008). Taborsky (1998) described male sneaking behavior in 140 fish species of 28 families.

However, studies on alternative reproductive strategies have only recently started in the context of biological fish invasions (McCallum et al. 2019). The round goby, Neogobius melanostomus (Pallas 1811), has invaded numerous ecosystems worldwide (Kornis et al. 2012) and often became highly abundant in invaded areas (e.g. Cerwenka et al. 2018). Reproductively active males are aggressive, defending territories or potential mating partners against intra- and interspecific competitors (Kornis et al. 2012). Females 
preferentially mate with larger (Stammler and Corkum 2005) and darker males (Yavno and Corkum 2011), or those combining both features (Kodric-Brown 1990).

In round goby males, two behavioral reproductive strategies can be distinguished, the parental and the sneaker strategy (Taborsky et al. 2008; Table 1). Parental males (conventional, type I, or bourgeois males) primarily invest in somatic growth, and they occupy and defend territories. In contrast, sneaker males (type II or parasitic males) preferentially invest in reproduction at the cost of growth; they do not express secondary sexual characters, are small-sized, and their coloration resembles females. Sneakers try to hide their male status by imitating females to fertilize foreign conspecific spawns (Taborsky et al. 2008). Sneaker round gobies have a light mottled coloration, larger accessory sperm glands, a higher sperm volume, reduced 11-ketotestosterone levels (all: Marentette et al. 2009), significantly larger testes, and heavier otoliths (both: Bose et al. 2018). In the upper Danube River in Germany, round goby invasion processes, including spread, autecology, and impact on other species are well-studied (Brandner et al. 2013a, b, 2015; Cerwenka et al. 2014, 2017, 2018). Based on evidence from many river systems worldwide, we hypothesize accordingly that round goby alternative male mating strategies are present there, too. Male round gobies $(n=312)$ were collected by electrofishing (ELT62-IID; Grassl GmbH, Berchtesgaden, Germany) from shorelines in a water depth of $\sim 60 \mathrm{~cm}$ in 2010 (March 29-October 18) and 2011 (April 11-October 20) at ten stretches along a $200 \mathrm{~km}$ section of the upper Danube River. Sex was determined based on the specific shape of the urogenital papilla (Marentette et al. 2009). Total length $\left(\mathrm{L}_{\mathrm{T}}\right)$ of investigated specimens ranged from 3.7 to $15.2 \mathrm{~cm}$ (mean $=9.7 \mathrm{~cm}, \mathrm{SD}=1.5 \mathrm{~cm})$.

To assign candidate sneaker males, body size (i.e. $\mathrm{L}_{\mathrm{T}}$ ) and energetic investment into reproduction, estimated as the gonado-somatic index were contrasted. The GSI was calculated as GSI $=100 \times \mathrm{M}_{\text {gonads- }}$ $\times \mathrm{M}_{\mathrm{S}}^{-1}$, where $\mathrm{M}_{\text {gonads }}$ is the weight of testes and seminal vesicles, and $\mathrm{M}_{\mathrm{S}}$ the weight of the eviscerated goby body. For doing so, (1) a piecewise regression (Ingle et al. 2015) of these two indices was used to identify dissimilar trends in different sections, i.e. a trend towards more male reproductive morphs; (2) a simplified threshold regression was applied to determine the particular $\mathrm{L}_{\mathrm{T}}$ at which the GSI separates these groups; and (3) finally, the lowest cut off of logtransferred GSI and the total sum of squares at both sides of morph groups determined the $\mathrm{L}_{\mathrm{T}}$ in combination with the GSI-threshold of $3 \%$ following Bleeker et al. (2017). Individuals not assignable to either sneakers or parental morphs were specified as intermediates (Table 2).

Individual trophic niche assignment of male round goby specimens was conducted using stable isotope analyses. Muscle tissue $\left(0.5-1.0 \mathrm{~cm}^{3}\right.$, Brandner et al. 2015) was used to determine the specimens' lipid content and to quantify the ecological differentiation of alternative reproductive strategies by stable isotope ratios of $\delta^{13} \mathrm{C}$ and $\delta^{15} \mathrm{~N}$.

Male round goby GSI varied between 0 and $9.6 \%$ and the calculated sneaker $\mathrm{L}_{\mathrm{T}}$ cut-off was $102 \mathrm{~mm} .14$ (4\%) specimens were classified as sneaker morphs. In contrast, $113(36 \%)$ specimens were classified as parental morphs and $185(59 \%)$ as intermediates. Male

Table 1 Size range (Total length $\left[\mathrm{L}_{\mathrm{T}}\right]$ or standard length $\left[\mathrm{L}_{\mathrm{S}}\right]$ in $\mathrm{mm}$ ) of male round goby reproductive morphs (sneaker, parental, intermediate), number of specimens analyzed, the invaded ecosystem and reference

\begin{tabular}{|c|c|c|c|c|}
\hline $\begin{array}{l}\text { n round } \\
\text { gobies }\end{array}$ & $\begin{array}{l}\text { Sneakers }(\mathrm{n})\left(\mathrm{L}_{\mathrm{T}} \text { or }\right. \\
\left.\mathrm{L}_{\mathrm{S}}\right)\end{array}$ & $\begin{array}{l}\text { Parentals }(\mathrm{n})\left(\mathrm{L}_{\mathrm{T}} \text { or }\right. \\
\left.\mathrm{L}_{\mathrm{S}}\right)\end{array}$ & Ecosystem & Study \\
\hline 295 & $151\left(\mathrm{~L}_{\mathrm{T}}: 43.5-90.3\right)$ & $144\left(\mathrm{~L}_{\mathrm{T}}: 61.5-161.0\right)$ & Jordan Harbour, Lake Ontario, Canada & $\begin{array}{l}\text { Marentette et al. } \\
\text { (2009) }\end{array}$ \\
\hline 1359 & $300\left(\mathrm{~L}_{\mathrm{T}}: 62.7-82.2\right)$ & $375\left(\mathrm{~L}_{\mathrm{T}}: 90.3-113.6\right)$ & $\begin{array}{l}\text { Hamilton Harbour, Lake Ontario, } \\
\text { Canada }\end{array}$ & $\begin{array}{l}\text { Marentette et al. } \\
(2010)\end{array}$ \\
\hline 69 & $28\left(\mathrm{~L}_{\mathrm{T}}:<9.35\right)$ & $35\left(\mathrm{~L}_{\mathrm{T}}:>9.35\right)$ & River Rhine, Netherlands & Bleeker et al. (2017) \\
\hline 341 & $134\left(\mathrm{~S}_{\mathrm{L}}: 36-95\right)$ & $207\left(\mathrm{~S}_{\mathrm{L}}: 5.0-11.9\right)$ & $\begin{array}{l}\text { Hamilton Harbour, Lake Ontario, } \\
\text { Canada }\end{array}$ & Bose et al. (2018) \\
\hline
\end{tabular}


Table 2 Sampling details (month, year, inhabited habitat, and time since invasion of the sampling site) and the number of male round goby mating morphs (sneaker, parental, intermediate)

\begin{tabular}{lllllcr}
\hline Year & Month & $\begin{array}{l}\text { Habitat } \\
\text { (artificial/natural) }\end{array}$ & $\begin{array}{l}\text { Invasion-history } \\
\text { (established/ } \\
\text { fronted-2009/ } \\
\text { fronted-2010) }\end{array}$ & Sneaker & Parental & Intermediate \\
\hline 2010 & 3 & $1 / 0$ & $0 / 1 / 0$ & 0 & 1 & 0 \\
2010 & 4 & $7 / 22$ & $29 / 0 / 0$ & 3 & 8 & 18 \\
2010 & 5 & $12 / 17$ & $29 / 0 / 0$ & 4 & 6 & 19 \\
2010 & 6 & $4 / 6$ & $10 / 0 / 0$ & 0 & 3 & 7 \\
2010 & 7 & $6 / 5$ & $6 / 5 / 0$ & 0 & 4 & 7 \\
2010 & 8 & $8 / 6$ & $8 / 6 / 0$ & 0 & 0 & 14 \\
2010 & 9 & $18 / 23$ & $39 / 0 / 2$ & 1 & 24 & 16 \\
2010 & 10 & $20 / 7$ & $27 / 0 / 0$ & 0 & 13 & 14 \\
Total & 2010 & $76 / 86$ & $148 / 12 / 2$ & 8 & 59 & 95 \\
2011 & 4 & $10 / 11$ & $16 / 5 / 0$ & 2 & 11 & 8 \\
2011 & 5 & $15 / 16$ & $29 / 0 / 2$ & 4 & 14 & 13 \\
2011 & 6 & $10 / 8$ & $18 / 0 / 0$ & 0 & 4 & 14 \\
2011 & 8 & $12 / 8$ & $14 / 6 / 0$ & 0 & 4 & 16 \\
2011 & 9 & $39 / 6$ & $34 / 0 / 11$ & 0 & 17 & 28 \\
2011 & 10 & $8 / 7$ & $15 / 0 / 0$ & 0 & 4 & 11 \\
Total & 2011 & $94 / 56$ & $126 / 11 / 13$ & 6 & 54 & 90 \\
\hline
\end{tabular}

Table 3 Trophic niche differentiation of alternative male round goby morphs (sneakers: $\mathrm{n}=13$, parentals: $\mathrm{n}=108$, intermediates: $\mathrm{n}=181$ )

\begin{tabular}{lll}
\hline & Sneakers & Parentals \\
\hline Sneaker $(\mathrm{C} / \mathrm{N}=3.31)$ & & \\
Parentals $(\mathrm{C} / \mathrm{N}=3.19)$ & $* *$ & \\
Intermediates $(\mathrm{C} / \mathrm{N}=3.26)$ & n.s. & $* * *$
\end{tabular}

Median lipid contents $(\mathrm{C} / \mathrm{N})$ of male morphs are given in parenthesis. Significant differences are indicated by stars $(* * * p<0.001, * * p<0.01)$, n.s. not significant

morph assignment was significantly correlated with divergent trophic niche occupation: lipid content was lowest in parental males and highest in sneaker males (Table 3); it was significantly higher in sneaker males than in parental (Bonferroni corrected Kruskal-Wallis test, $p<0.01$ ) and intermediate morphs (Bonferroni corrected Kruskal-Wallis test, $p>0.05$ ). Differences in parental and intermediate morphs were highly significant.

\section{Discussion}

This study provides evidence for the occurrence of alternative male mating strategies in round goby during their ongoing invasion of the upper Danube River (Table 2). Although this finding is novel in the context of a biological invasion process in the upper Danube River, alternative male mating strategies had been inferred for other round goby invasions, but with substantially different proportion estimates: whereas only about $4 \%$ round gobies were identified as sneakers in the invaded upper Danube River, much higher values of $40.6 \%$ in the River Rhine in the Netherlands (Bleeker et al. 2017), and 39.3\% (Bose et al. 2018), 12 and 51\% (Marentette et al. 2009, 2010) in the Great Lakes in the USA were found. A comparison of such proportions is challenging, however, because populations have different (invasion) histories, and exhibit different densities of conspecific and interspecific competitors (Cerwenka et al. 2018), among other parameters. Yet, Marentette et al. (2009) hypothesized a positive correlation of round goby sneaker ratio with time since invasion, which is supported by our analysis of the recent invasion process in the upper Danube River: sneaker morphs 
are expected to occur less likely at the beginning of an invasion and are likely to become more numerous once the species is established. Accordingly, Kornis et al. (2012) suggest an increase in competition between males with increasing time since invasion and thus a likely increase of sneaker abundance after the carrying capacity of the invaded ecosystem is reached. Alternatively, different origins and genetic constitutions of invasive populations might affect male reproductive strategy distribution, too. Indeed, round goby populations of the upper Danube River differ genetically (Cerwenka et al. 2014), and it cannot be excluded that they have originated from different source populations; yet, there is no evidence that genetic differences are linked with alternative behavioral strategies. Furthermore, differences and limitations of study designs need to be considered: (1) different sampling methods [this study: electrofishing, Gertzen et al. (2016): beach seining, Bleeker et al. (2017): bottom-trawling and electrofishing, Bose et al. (2018): minnow traps] differ in selectivity, although electrofishing is the most unselective one (Brandner et al. 2013b); (2) fish size representation may affect morphs to be over- or underrepresented (small sneaker individuals and large parental morphs may both be underrepresented while intermediate morphs may be over-represented in our study); (3) female-like coloration of sneakers may have led to eroneous sexing in the field, because morphological inspection of genital papillae is sometimes difficult under field conditions; (4) sneaker male occurrence might vary with sampling season: Gertzen et al. (2016) reported sneaker males to occur until the end of European summer, whereas specimens in this study were collected from April through October. However, GSI values of round goby specimens did not significantly vary between months in this study (Bonferroni corrected Kruskal-Wallis test, all: $p=1$ ); (5) individual hatching date may influence reproductive life history decisions (Bleeker et al. 2017), because males may have a smaller body size at the beginning of the first breeding season; and, finally, (6) mortality and migration propensities of morphs may vary according to different sneaker frequencies at collection spots (Marentette et al. 2010).

The individual trait hypothesis (Cerwenka et al. 2017) might provide a further explanation for alternative attributes within a population. Three of the candidate sneaker round goby specimens identified in the present study (21\%) had outlying individual trait values in the study of Cerwenka et al. (2017): all three featured exceptional high lipid contents ( $>4.1$, Table 3). Parentals might have increased metabolism and thus reduced energy storage amounting in lipid content though to nest defense, signaling, and courtship behavior (Svensson et al. 2004).

Sneaking seems not to be genetically determined but may be used in the early ontogeny of smaller-sized male round goby adults, primarily (Marentette et al. 2009). Its frequency is constrained by multiple different factors and thus the study design is the crucial factor for detecting this common behavioral alternative reproductive strategy.

Acknowledgements We thank all the friendly and helpful owners of the local fishing rights, the "Fischereifachberatungen", and Dr. G. Zauner who supported our sampling. Further, we want to thank Prof. Dr. Karl Auerswald and Dr. Rudi Schäufele (both: Technische Universitaet Muenchen) for processing stable isotope analyses and two anonymous reviewers for their helpful advice. This project was funded by the German Research Council DFG, project-number SCHL 567/5-1 and GE 2169/1-1 (AOBJ: 569812).

Funding Open Access funding enabled and organized by Projekt DEAL.

Open Access This article is licensed under a Creative Commons Attribution 4.0 International License, which permits use, sharing, adaptation, distribution and reproduction in any medium or format, as long as you give appropriate credit to the original author(s) and the source, provide a link to the Creative Commons licence, and indicate if changes were made. The images or other third party material in this article are included in the article's Creative Commons licence, unless indicated otherwise in a credit line to the material. If material is not included in the article's Creative Commons licence and your intended use is not permitted by statutory regulation or exceeds the permitted use, you will need to obtain permission directly from the copyright holder. To view a copy of this licence, visit http://creativecommons.org/licenses/by/4.0/.

\section{References}

Bleeker K, De Jong K, Van Kessel N et al (2017) Evidence for ontogenetically and morphologically distinct alternative reproductive tactics in the invasive round Goby Neogobius melanostomus. PLoS ONE 12:1-13. https://doi.org/10. 1371/journal.pone. 0174828

Bose APH, McCallum ES, Raymond K et al (2018) Growth and otolith morphology vary with alternative reproductive 
tactics and contaminant exposure in the round goby Neogobius melanostomus. J Fish Biol 93:674-684. https:// doi.org/10.1111/jfb.13756

Brandner J, Auerswald K, Cerwenka AF et al (2013a) Comparative feeding ecology of invasive Ponto-Caspian gobies. Hydrobiologia 703:113-131. https://doi.org/10.1007/ s10750-012-1349-9

Brandner J, Cerwenka AF, Schliewen UK, Geist J (2013b) Bigger Is better: characteristics of round gobies forming an invasion front in the Danube River. PLoS ONE. https://doi. org/10.1371/journal.pone.0073036

Brandner J, Auerswald K, Schaufele R et al (2015) Isotope evidence for preferential dispersal of fast-spreading invasive gobies along man-made river bank structures. Isot Environ Health Stud 51:80-92. https://doi.org/10.1080/ 10256016.2014.993978

Cerwenka AF, Brandner J, Geist J, Schliewen UK (2014) Strong versus weak population genetic differentiation after a recent invasion of gobiid fishes (Neogobius melanostomus and Ponticola kessleri) in the upper Danube. Aquat Invasions 9:71-86

Cerwenka AF, Pagnotta A, Böker C et al (2017) Little association of biological trait values with environmental variables in invasive alien round goby (Neogobius melanostomus). Ecol Evol 7:4076-4085. https://doi.org/ 10.1002/ece3.2942

Cerwenka AF, Brandner J, Schliewen U, Geist J (2018) Population trends of invasive alien gobies in the upper Danube River: 10 years after first detection of the globally invasive round goby (Neogobius melanostomus). Aquat Invasions 13:525-535. https://doi.org/10.3391/ai.2018.13.4.10

Gertzen S, Fidler A, Kreische F et al (2016) Reproductive strategies of three invasive Gobiidae co-occurring in the Lower Rhine (Germany). Limnol Ecol Manag Inland Waters 56:39-48. https://doi.org/10.1016/j.limno.2015.10. 005

Ingle AN, Sethares WA, Varghese T, Bucklew JA (2015) Piecewise linear slope estimation. In: Conference record Asilomar conference signals, system computers 2015 April, pp 420-422. https://doi.org/10.1109/ACSSC.2014. 7094476

Kodric-Brown A (1990) Mechanisms of sexual selection: insights from fishes. Ann Zool Fenn 27:87-100
Kornis MS, Mercado-Silva N, vander Zanden MJ (2012) Twenty years of invasion: a review of round goby Neogobius melanostomus biology, spread and ecological implications. J Fish Biol 80:235-285. https://doi.org/10. 1111/j.1095-8649.2011.03157.x

Marentette JR, Fitzpatrick JL, Berger RG, Balshine S (2009) Multiple male reproductive morphs in the invasive round goby (Apollonia melanostoma). J Great Lakes Res 35:302-308. https://doi.org/10.1016/j.jglr.2009.01.009

Marentette JR, Gooderham KL, McMaster ME et al (2010) Signatures of contamination in invasive round gobies (Neogobius melanostomus): a double strike for ecosystem health? Ecotoxicol Environ Saf 73:1755-1764. https://doi. org/10.1016/j.ecoenv.2010.06.007

McCallum ES, Bose APH, Lobban N et al (2019) Alternative reproductive tactics, an overlooked source of life history variation in the invasive round goby. Can J Fish Aquat Sci 76:1562-1570. https://doi.org/10.1139/cjfas-2018-0340

Stammler KL, Corkum LD (2005) Assessment of fish size on shelter choice and intraspecific interactions by round gobies Neogobius melanostomus. Environ Biol Fishes 73:117-123. https://doi.org/10.1007/s10641-004-5562-X

Svensson O, Nyman A, Kvarnemo C (2004) Costly courtship or dishonest display? Intensely displaying sand goby males have lower lipid content. J Fish Biol 64:1425-1429. https:// doi.org/10.1111/j.0022-1112.2004.00381.x

Taborsky M (1998) Sperm competition in fish: bourgeois' males and parasitic spawning. Trends Ecol Evol 13(6):222-227

Taborsky M, Oliveira RF, Brockmann HJ (2008) The evolution of alternative reproductive tactics: concepts and questions. Altern Reprod Tactics Integr Approach. https://doi.org/10. 1017/CBO9780511542602.002

Yavno S, Corkum LD (2011) Round goby Neogobius melanostomus attraction to conspecific and heterospecific egg odours. J Fish Biol 78:1944-1953. https://doi.org/10. $1111 /$ j.1095-8649.2011.02964.x

Publisher's Note Springer Nature remains neutral with regard to jurisdictional claims in published maps and institutional affiliations. 